\title{
Improving Coherence of The Students' Sentences by Applying Thematic Progression And Personal Blog In The Sentence-Based Writing Class
}

\author{
Arif Suryo Priyatmojo \\ Faculty Of Languages And Arts \\ Semarang State University \\ Arifsuryo.Unnes@Gmail.Com
}

\begin{abstract}
This study was aimed at describing what kinds of thematic progression patterns mostly employed by the students, describing how to apply thematic progression theory and personal blog in the sentence-based writing class, and finding out whether the use of thematic progression theory and personal blog give positive significances to coherence of the students' sentences. This is an action research study employing two cycles. The subject of the study was 24 students of group 2, in a class of sentence-based writing (SBW), and the object of the study was students' sentences created by the students in the teaching and learning process (TLP). The result of the study shows that thematic progression patterns moslty employed by the students are constant theme pattern followed by zig zag and multiple theme patterns. In TLP, the materials were devided and given to the students in two cycles. The first cycle focused on introducing the thematic progression theory and its kinds of patterns. Then, in the next cycle the students focused on sharing ideas with other classmates via individual blogs. Based on the result of the study, teaching SBW using thematic progression theory gives its positive significance by varied patterns used by the students. It can be seen from the analysis of the students' sentences from pretest, paragraf 1, paragraf 2, paragraf 3 and posttest. The students also give positive responses upon its teaching and learning process using thematic progression and personal blogs based
\end{abstract}


on the pre and post test questionnaire data. It is hoped that the result of the study gives positive contribution to the students in preparing them to write in bigger contexts - paragraph-based writing, genre-based writng and academic writing in the next coming semesters.

Keywords: Thematic Progression, Theme Rheme, Thematization, Personal Blog

\section{Abstrak}

Penelitian ini bertujuan untuk mendeskripsikan apa jenis pola perkembangan tematik yang sebagian besar digunakan oleh siswa, menjelaskan bagaimana menerapkan teori perkembangan tematik dan blog pribadi dalam kalimat berbasis kelas menulis, dan mencari tahu apakah penggunaan teori perkembangan tematik dan blog pribadi memberikan signifikansi positif terhadap koherensi kalimat siswa . Ini merupakan studi penelitian tindakan dengan dua siklus. Subyek penelitian ini adalah 24 siswa dari kelompok 2, dalam kelas berbasis kalimat menulis (Sentence-Based Writing-SBW ), dan obyek penelitian ini adalah kalimat yang dibuat oleh mahasiswa dalam proses belajar mengajar (Teaching and Learning Process-TLP ). Hasil penelitian menunjukkan bahwa pola perkembangan tematik yang banyak digunakan oleh siswa yaitu pola tema tetap diikuti oleh zig zag dan beberapa pola tema . Di TLP, materi dibagi dan diberikan kepada siswa dalam dua siklus. Siklus pertama difokuskan pada memperkenalkan teori perkembangan tematik dan macam-macam pola. Kemudian, pada siklus berikutnya siswa difokuskan pada berbagi ide dengan teman sekelas lain melalui blog masing-masing. Berdasarkan hasil penelitian, mengajar SBW menggunakan teori perkembangan tematik memberikan makna positif oleh pola bervariasi yang digunakan oleh para siswa. Hal ini dapat dilihat dari analisis kalimat siswa dari pretest, paragraf 1, paragraf 2, paragraf 3 dan post test. Para siswa juga memberikan respon positif terhadap proses belajar mengajar dengan menggunakan perkembangan tematik dan blog pribadi yang didasarkan pada sebelum dan setelah data tes kuesioner. Diharapkan hasil penelitian ini memberikan kontribusi positif bagi siswa dalam mempersiapkan mereka untuk menulis dalam konteks yang lebih besar- paragraf berbasis menulis (paragraph-based writing), berdasarkan genre writng dan menulis akademik di semester yang akan datang. 
Kata kunci : Perkembangan Tematik, Tema Rheme, Tematisasi, Blog Pribadi

\section{Introduction}

Writing is one of the four skills in English from which students are supposed to master besides listening, speaking and reading. Those skills are classified into two main skills - receptive and productive skills. Here, writing is classified into a productive skill as the students are demanded to be able to write in the forms of sentences, paragraphs, essays and texts. This is due to its main objective of writing, the students have literacy in writing. Literacy is defined as the students' competence in communicating messages (Paltridge, 2001:4).

The students doing writing gives some significances. First, the students can explore their ideas or opinions. Then, writing is one of the academic demands. Moreover, writing belongs to the epistemic level for the students. It is based on the literacy level proposed by Wells (1987). Based on this level, the students are supposed to have skills in writing started from the basic one, sentence-based writing, from which they are going to meet other writing activities namely paragraph-based writing, genre-based writing and academic writing. The purpose of those writing activities is the students' competence in communicating meaningful messages for the readers.

Sentence-based writing is one of the course subjects given to the students in the second semester. Before they get this subject, the students learn intensive writing in the first semester. Furthermore, the materials given are quite simple. For example, they have to rewrite words, phrases, 
clauses and sentences. As a result, they do not explore their ideas. Here, the writer only taught one class consisting of 24 students. Based on textual observation and analysis, it was found that some students still had difficulties in writing coherent sentences. They also gave some arguments in the questionnaires which indicated their weaknesses due to some considerations; they were not only about the structure of the sentences but also coherency of the sentences.

The followings are some comments given by the students based on one of the questions in the pre questionnaires "Did you use to practice writing sentences and find its difficulties?" Intan Adi Setyaningrum, one of my students said that she liked writing even it was not an easy job to do:

"In my opinion, there must be some rules especially grammar if I would like to write sentences. As a result, I should pay attention in that process". (pre-questionaire)

Then, another comment was given by Ela Julaeha:

"It is not easy to write sentences in English. I have to practice a lot how to write good sentences and paragraphs. I do practice every day, but it is still difficult indeed". (pre-questionaire).

Moreover, Haifa Khairunnisa provided her different point of view:

"We are not only aware of grammar but also other things such theme and rheme, and thematic progression patterns (prequestionaire).

It is very interesting to analyse Haifa's comment as I assumed she has already read some references about how to write coherent sentences. It seemed that she had copied and read the books recommended by the lecturer in the first meeting. Those comments indicated that some students still had less knowledge of producing sentences. Based on the 
elaboration above, the writer was interested in conducting a research. $\mathrm{He}$ tried to find out whether thematic progression theory could be applied in sentence-based writing class and it has positive significances.

The writer was also highly interested in employing personal blog as a sharing medium among the students. It was because most of the students have not used the blog maximally for academic purposes. Based on the questionnaire, most of the students were highly literate with the use of personal blog, but they did not use for English writing activities. They just used it as media for sharing their ideas, status, opinions in which they were still in Indonesia. It could be ilustrated by the following comments related to the use of personal blog "Do you know and have a personal blog. If yes, how can you use it?"

First comment given by Nuki Nurazizah:

"I know about personal blog as some of my friends have it. I do so. I made it a couple of years ago the purpose of which was for sharing with others. It can be many things. But, I rarely use it nowadays." (pre-questionaire)

Then, Sri Utami provides her comment as the following:

"I knew personal blog when I was in senior high school as we had computer subject in which the teacher demanded us to create our personal blog. I also have a personal blog to write my short stories and poems". (pre-questionaire)

Nizar Religia gives his comment:

"Before I join at UNNES, I have heard lots of things about blog. At first I was not quite interested in having that, but I started writing my text in my new blog and I like it. Now I have my own blog and it can improve my sentences" (pre-questionaire) 
Those are some comments given by some students. It can be inferred that some students were acknowledged with the personal blog and its varied use for different purposes. Furthermore, they did not use it as media for them for sharing with others. Such case interested the writer to apply personal blog in the sentence-based writing class.

Based on significances, elaborations and identified problems, the writer conducted the research. The purposes of the study are to find out what kinds of thematic progression patterns mostly used by the students; how to apply thematic progression and personal blog in the teaching and learning process; to what extent thematic progression and personal blog give positive contribution for the students.

\section{Theme and rheme}

Theme and rheme are terms describing how information is explored in a sentence. According to Butt.et al (1995:38) theme is the information which is clearly understood by readers, the function of which, is as "the point of departure" in an information. It has been stated in a text or it is based on contextual understanding. The information can be in the forms of characters, process or circumstances.

On the other hand, rheme is defined as a new information in a clause within sentences developed from theme (Eggins, 1994: 275). The information is knowledge assumed by the writer that is unclearly understood by the readers, but it needs to be informed in order to the development of the information in the sentences. We can easily identify that theme is the first element occurred in the beginning of the clause; the rest is the rheme. 
Theme and rheme classification can be ilustrated as the following examples:

The man in the moon

Mr. Smith and his rival

On the first day of Lebaran

On Sunday morning

On a rainy day

Theme came down too soon

were fighting for the crown

we went around to meet other people

my love came to my house

we invited our close friend

Rheme

We can identify three different clause elements categorized as theme based on three dimensional metafunctional structure: topical/experiential element, interpersonal element dan texstual element (Eggins, 1994: 276).

\section{Topical Theme}

Eggins $(1994,276)$ states that an element of a clause functioning as transitivity (Actor, Behaver, Senser or Circumstance) is categorized as topical theme. A main principal is that there should be a topical theme in a clause. After we can identify a theme in a clause, the rest must be the rheme.

\section{Table 1}

Example of Topical Theme

\begin{tabular}{|l|l|}
\hline Infants & Cry and fuss for a mean of $13 / 4 \mathrm{hr} /$ day at age 2 weeks \\
\hline Behaver & \\
\hline Theme & Rheme \\
\hline
\end{tabular}

(Source: Eggins, 1994: 277)

\section{Textual Theme}

Some writers often use experiental meanings using words or phrases to connect a message with the previous text. By doing this, the 
writers have created a coherent text. Conjunctions are mostly used in clauses here. Eggins $(1994,281)$ states that textual themes are elements which do not express interpersonal and experiental meanings. Eggins classify textual theme into continuity adjuncts and conjunctive adjuncts. Continuity adjuncts are related with some expressions used in utterances such as oh, well, yea and no. Meanwhile, the conjcunctive adjuncts funsctions to combine clauses or sentences. It can be applied using conjunctions.

Table 2

Example of Textual Theme

\begin{tabular}{|l|l|l|}
\hline And & They & went on their journey \\
\hline But & I & was still happy \\
\hline Nevertheles & all students & enjoyed the trip \\
\hline And os & the teacher & gave some assignment \\
\hline Textual & Topical & \multirow{2}{*}{ Rheme } \\
\hline Theme &
\end{tabular}

\section{Interpersonal theme}

Interpersonal themes are used by the writers when they start writing sentences with clauses functioning as interpersonal meanings indicating kinds of interactions. Butt et al. (1995: 94) group interpersonal themes into finite in interrogative clause, initial vocatives, mood and common adjunct. 
Table 3

Example of Interpersonal Theme

\begin{tabular}{|l|l|l|}
\hline May & We & $\begin{array}{l}\text { have some butter for the royal } \\
\text { slice of bread? }\end{array}$ \\
\hline Assuredly Madam & We & will grant for your request \\
\hline Could & the team & have beaten the grand finalists? \\
\hline Probably & They & Could \\
\hline Interpersonal & Topical & \multirow{2}{*}{ Rheme } \\
\hline \multicolumn{2}{|l}{ Theme } &
\end{tabular}

\section{Thematic progression}

Thematic progression is a way used by the writers to create sentences in a text. It can be done by putting the previous theme or rheme into new themes. Eggins (1994: 302) classifies three kinds of thematic models: theme re-iteration/ constant theme pattern, zig-zag pattern and multiple theme pattern.

\section{Theme re-iteation/ constant theme pattern}

This model is considered as the simplest pattern in writing sentences. It just repeats an element (Eggins, 1994: 303). It does not have varied thematization patterns. New themes are taken from the previous themes.

\section{Table 4}

Example of constant theme pattern

\begin{tabular}{|ll|}
\hline Theme & Rheme \\
My friends and I & went to Jakarta last holiday \\
We & visited some places there \\
We & also spent our holiday by visiting Ancol and Dufan \\
My friends and I & were very happy \\
\hline
\end{tabular}

(source: Butt et.al, 1995:99) 
Figure 1

Thematic Progression: Theme reiteration/constant theme pattern.

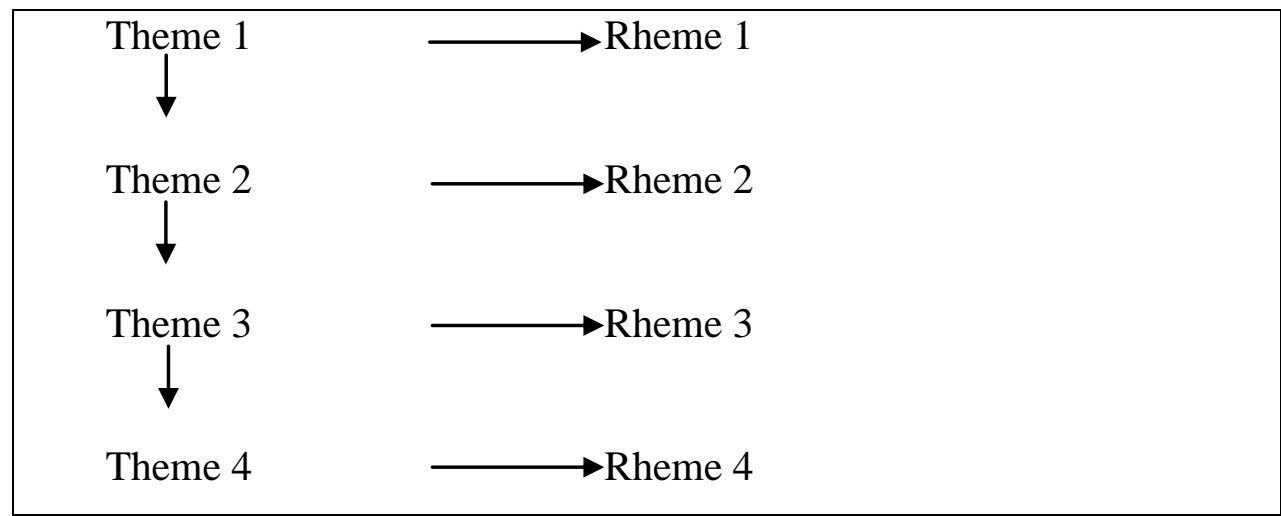

\section{Zigzag/linear theme}

In this uses zig zag pattern, a rheme is placed as the new theme in the next clause.

Table 5

Example of zig zag pattern

\begin{tabular}{|ll|}
\hline Theme & Rheme \\
On Saturday night & my friends and I went to Lawang \\
Sewu & is well-known as the living place for \\
It & \\
ghost &
\end{tabular}

(source: Butt et.al, 1995:99)

Figure 2

Thematic Progression: A zigzag/linear theme pattern

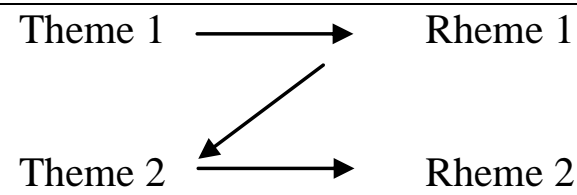




\section{A multiple theme/split rheme pattern}

The last pattern combines the previous patterns. It is called as multiple theme pattern. In this pattern, a rheme can have many informations and this rheme may arrise some new themes (Eggins, 1994: 304).

\section{Table 6}

Example of multiple theme pattern

\begin{tabular}{|ll|}
\hline On Saturday, & $\begin{array}{l}\text { my colleague and I went to Jakarta. } \\
\text { se }\end{array}$ \\
st & $\begin{array}{l}\text { had lots of rooms and restaurants } \\
\text { consisted of economical and luxuries even } \\
\text { president suit class } \\
\text { offered many kinds of menus from different } \\
\text { countries } \\
\text { Rheme }\end{array}$ \\
The restaurants & \\
Theme & \\
\hline
\end{tabular}

(source: Butt et.al, 1995:100)

Figure 3

Thematic progression: multiple theme pattern

\begin{tabular}{|c|c|}
\hline Clause1 T1 & R1 \\
\hline On Saturday & my ... Jakarta \\
\hline Clause2 T2 - & $\mathrm{R} 2$ \\
\hline We & stayed ... Hotel \\
\hline Clause3 T3 & R3 \\
\hline It & had ... restaurants \\
\hline Clause4 T4 & R4 \\
\hline The room & consisted ... class \\
\hline Clause5 T5 & R5 \\
\hline The restaurants & offered ... countries \\
\hline
\end{tabular}


Research Methodology

The writer used action research method in this study employing two cycles based on the progress of teaching and leraning process. The following is the research cycle based on Kemmis and Mc. Taggart (1988):

Figure 4

Action research cycles based on Kemmis and Mc. Taggart (1988) cited in Burns (2010: 9).

CYCLE 1

CYCLE 2

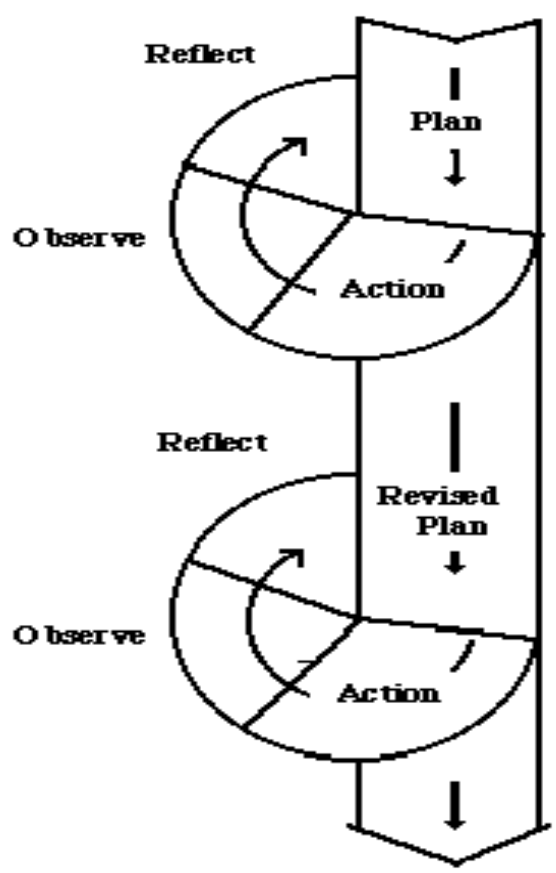




\section{Subject of the study}

The subject of the study was 24 students, in the second semester, taking a sentence-based writing class (subject code: BIN 108)

\section{Object of the study}

The sentences produced by the students were the object of the study. They were analysed using thematic progression theory to find out the coherence of the sentences taken in the students' personal blogs. The number of the analysed paragraph was not only one paragraph, but it was based on the teaching and learning process. Before the researcher analysed the sentences, he demanded the students to put their work on their own blog in case it enabled the researcher to analyse anytime.

\section{Setting of time and place}

The research took 6 months to complete based on the teaching and learning progress. It was conducted in the English department, faculty of languages and arts, UNNES. The action research was based on the proposed schedule, in B3-317 building.

\section{Steps of doing action research}

\section{Problem identification}

In identifying the problem, the writer demanded the students to do exercises and assignment in the classroom before main activities of TLP. Moreover, their works were uploaded in their own blogs, the purpose of this, was to get early observation in analysing the students' competence in writing sentences. It became an indicator to plan the research.

Data gathering 
As the object of the study was in the form of sentences, so the data was taken from its analysis using thematic progression theory.

\section{Data interpretation}

After analysing the students' sentences using thematic progression theory, the researcher identified and classified based on its purposes. Action

This research employed two cycles, so the teaching materials of the thematic progression theory was devided into two activities. The first activity was the introduction of theme and rheme within clauses. Later, the focus of TLP was similar with the previous one, but in deeper discussion. To ease the description of TLP, here was the teaching and learning process:

Table 7

Action in the first cycle

\begin{tabular}{|l|l|l|}
\hline \multirow{5}{*}{ CYCLE 1 } & \multicolumn{1}{|c|}{ Activities } & \multicolumn{1}{c|}{ Materials } \\
\cline { 2 - 3 } & $\begin{array}{l}\text { TLP } \\
\text { Discussion } \\
\text { Question \& answer } \\
\text { Practice }\end{array}$ & $\begin{array}{l}\text { Introduction of theme } \\
\text { and rheme }\end{array}$ \\
\cline { 2 - 3 } & $\begin{array}{l}\text { TLP } \\
\text { Discussion } \\
\text { Question \& answer } \\
\text { Practice }\end{array}$ & $\begin{array}{l}\text { Introduction of thematic } \\
\text { progression }\end{array}$ \\
\cline { 2 - 3 } & Writing Practice & Free topics \\
\hline
\end{tabular}

After evaluating the first cycle, the researcher planned to conduct the second cycle.

Table 8

Action in the second cycle 


\begin{tabular}{|l|l|l|}
\hline & \multicolumn{1}{|c|}{ Activities } & \multicolumn{1}{c|}{ Materials } \\
\cline { 2 - 3 } & $\begin{array}{l}\text { TLP } \\
\text { Discussion } \\
\text { Question \& answer } \\
\text { Practice }\end{array}$ & Theme and rheme \\
\cline { 2 - 3 } CYCLE 2 & $\begin{array}{l}\text { TLP } \\
\text { Discussion } \\
\text { Question \& answer } \\
\text { Practice }\end{array}$ & Thematic progression \\
\cline { 2 - 3 } & Writing Practice & $\begin{array}{l}\text { Enlarged from the } \\
\text { previous topics in the } \\
\text { first cycle. }\end{array}$ \\
\hline
\end{tabular}

\section{Instrument}

The instruments used in the research were:

a. Observation. It was refered as textual analysis on the sentences produced by the students based on every meeting demanding them to produce sentences.

b. Test. Pretest and posttest were used to measure the outcome of TLP, but they were not as the main assessment as the students did writing activities in every meeting.

c. Questionnaires. To find out the students' responses related to the use of thematic progression and personal blog in the sentence-based writing class, pre and post questionnaires were used. Both were used to find out the students responses upon TLP. 


\section{Discussion}

Based on TLP using thematic progression and personal blog, the result shows that the students varied their sentences based on thematic progression theory. It can also be seen from the number of clauses produced by the students: pretest 227 clauses, 220 clauses, 269 clauses, 275 clauses, and 263 clauses. The following figure describes the number of clauses:

\section{Figure 5}

The number of clauses

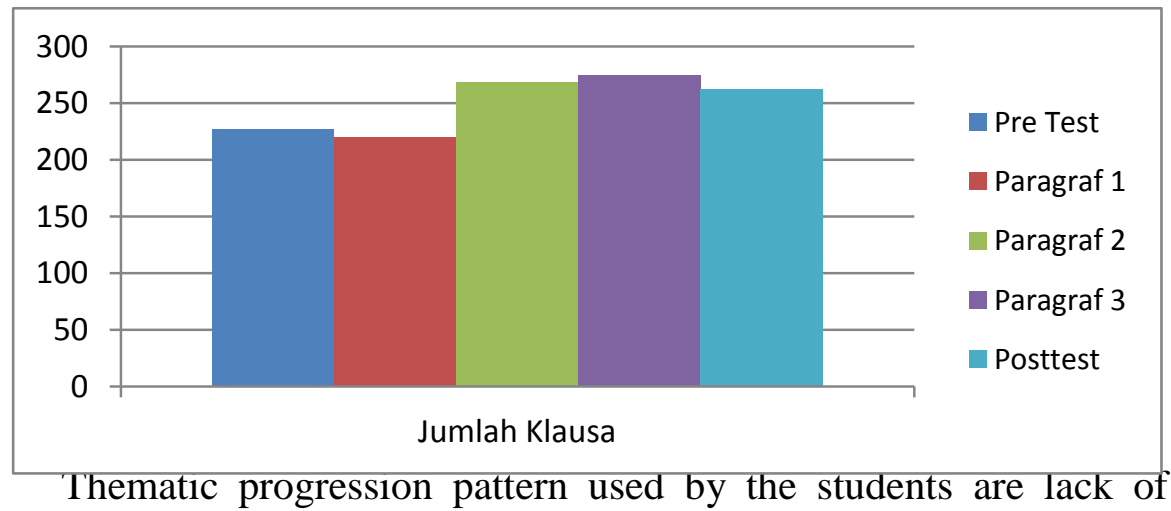

consistency. Furthermore, it is very interesting to see from the development of zigzag pattern. On the pretest, the number of this pattern is $14 \%$, but on the following paragpraphs the percentage of the clauses are $21.36 \%, 21.8 \%, 20 \%$ dan $22.43 \%$. It indicated that the students started using rheme into new themes to the following clauses. Here is the figure describing kinds of thematic progression patterns used by the students: 
Figure 6

Thematic progression patterns

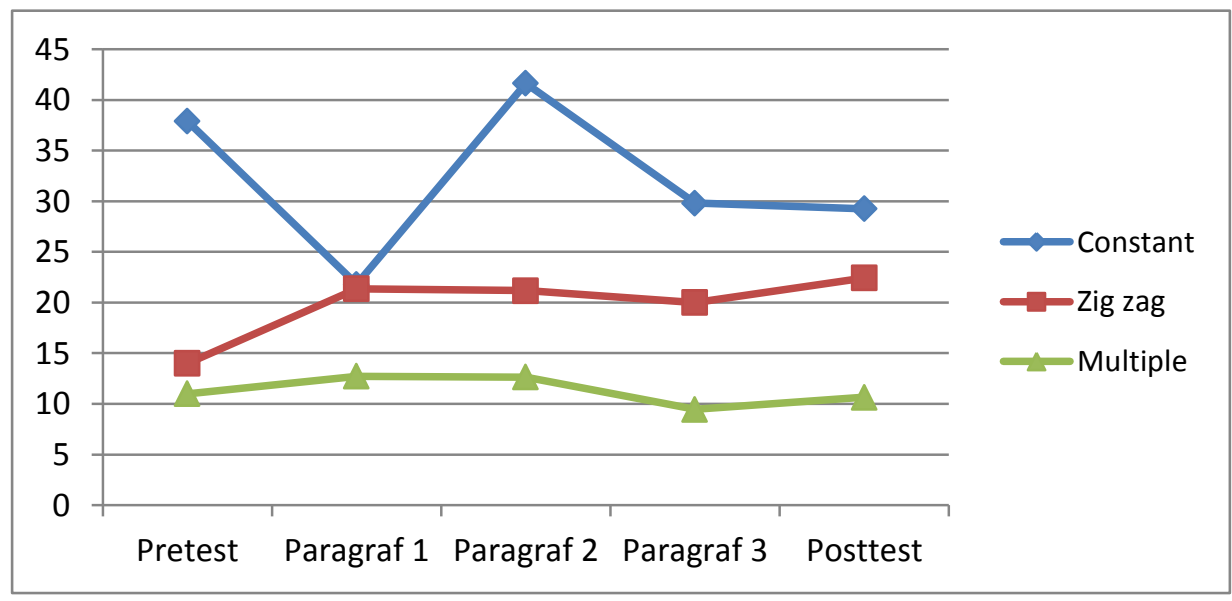

Referring to the blog used by the students as the media in TLP of the sentence-based writing class, the blog gives positive contribution for the students. It can be seen from the responses of the students. It affects to the students' sentences quality. Based on the observation and evaluation, the researcher concludes that the use of thematic progression and personal blog improve some aspects of students sentence writing, even not for all aspects.

\section{Conclusion and suggestion}

\section{Conclusion}

Based on the analysis and result of the research finding, some conclusions are as follow:

1. The students produced sentences using three patterns. Constant pattern dominates the two other patterns. In the pretest activity, the precentage of three patterns are constant with $37.9 \%$, zigzag with $14.1 \%$ and multiple with $11 \%$. Then, in paragraph 1 , the number of 
precentages has changed. For example, the number of constant pattern is $21.81 \%$ followed with zig zag pattern with $21.36 \%$ and multiple pattern with $12.72 \%$. It is very interesting to analyse it as the students did not focus on constant pattern only. Moreover, in paragraph 2 the students tend to go back to the previous pattern. It can be seen from the number of clauses $-41.63 \%$ dominating other patterns as their clauses are stable, zig zag with $21.18 \%$ and multiple pattern with $12.64 \%$. In addition, in paragraph 3 the number of clauses on three patterns are decreasing $-29.82 \%, 20 \%$ and $9.45 \%$. It can be affected by the students who did not concentrate on TLP but they focused on how to share ideas via personal blogs. Finally, in the post-test the percentage of three patterns are $29.27 \%, 22.43 \%$ and $10.64 \%$.

2. Teaching and learning process using thematic progression was devided into some meetings. In the early meetings, the students learned about basic skills of writing coherent sentences. Then, they were demanded to write a paragraph consisting of minimally 10 sentences with their own topics. After that, the students learned more about the materials in the next meetings. The students also used personal blog as sharing media with others. Personal blog was focused in the second cycle.

3. The use of thematic progression gives positive contribution for the students' sentences. It can be seen from the varied number of patterns which does not only focus on constant pattern. Though they do not increase significantly, by the varied number of patterns it indicates that the students are getting aware of writing coherent 
sentences. In addition, it is supported by the responses given by the students in the questionnaires.

\section{Suggestions}

Some suggestions are as follows:

1. Thematic progression theory needs to be learned by the students in the sentence-based writing class;

2. The students need to practice a lot in writing sentences not only in the classroom but also outside of the classroom;

3. In intensive writing class, the students should be given opportunities to freely explore their ideas;

4. It needs time for the researcher to analyse the students' sentences as it takes time to do such analysis.

\section{References}

Burns, Anne. 2010. Doing Action Research in English Language Teaching: A Guide for Practitioners. Oxon: Routledge

Butt. et al. 1995. Using Functional Grammar: An Explorer's Guide. Sydney: National Centre for English Language and Research Macquaire University

Eggins, Suzanne. 1994. An Introduction to Systemic Functional Linguistics. London: Pinter Publsiher

Oshima, Alice \& Hogue, Ann. 1999. Writing Academic English. New York: Pearson 
Paltridge, Brian. 2001. Genre and the Language Learning Classroom. Michigan: The University of Michigan Press.

Wells, G. 1987. Apprenticeship in Literacy. In Interchange 18, 1/2: 109123.

Witte, Stephen P. \& Faigley, Lester. 1981. Coherence, Cohesion and Writing Quality. College Composition and Communication, 32, 189-204. 